\title{
TRADITIONAL MARKET AND WOMEN'S WORK IN THE BERINGHARJO MARKET, OF YOGYAKARTA
}

\author{
Budiawati Supangkat, ${ }^{1}$ Rahman Latif Alfian, ${ }^{2}$ and Johan Iskandar ${ }^{3}$ \\ ${ }^{1}$ Department of Anthropology, Faculty of Social Science and Political Science, Unpad, Jatinangor Campus, Jl. Raya \\ Bandung-Sumedang KM21, Sumedang 45363, West Java \\ ${ }^{2}$ Freelance Researcher, Alumni of Postgraduate of Anthropology, Faculty of Social Science and Political Science, Unpad. \\ ${ }^{3}$ Department of Biology, Faculty of Mathematics and Natural Sciences and Postgraduate of Environmental Science \\ (PSMIL \&DIL) Unpad, Jatinangor Campus, Jl. Raya Bandung-Sumedang Km 21, Jatinangor, Sumedang 45363, West \\ Java, Phone. +62-22-77912. \\ E-mail: budiawati.supangkat@unpad.ac.id ; rahmanlatif927@gmail.com ; johan.iskandar@unpad.ac.id
}

\begin{abstract}
Traditional market is often one of the locations for economic turnover in an area. Various goods from villages, subdistricts, and other areas around the city are sent to be traded. In this market there is a large system that makes the market "live" in which there are interrelated actors. Some of the actors in the traditional market system such as the Beringharjo Market are women who work odd jobs. To see this phenomenon, this study used an ethnographic method to delve deeper into the phenomena that occur from the point of view of stakeholders in Beringharjo Market. The results of study showed that Beringharjo Market always changes from time to time, both physically and the actors who "live it". Women who work in al kind of work become one of the actors who play an important role in the sustainability of dynamic market activities.
\end{abstract}

Keywords: Traditional market; women; women worker; Beringharjo market

\section{PASAR TRADISIONAL DAN PEREMPUAN PEKERJA SERABUTAN DI PASAR BERINGHARJO, DAERAH ISTIMEWA YOGYAKARTA}

\begin{abstract}
ABSTRAK. Pasar tradisional di kota seringkali menjadi salah satu lokasi tempat perputaran ekonomi di suatu wilayah. Berbagai barang dari desa, kecamatan, maun daerah-daerah lain biasa dikirim ke pasar-pasar tradisional di kota. Pasar tradisional bergerak secara dinamik dan 'sangat hidup' secara berkelanjutan, antara lain karena didukung oleh berbagai aktor yang saling terkait. Di antara berbagai aktor tersebut adalah para perempuan pekerja serabutan. Tujuan penelitian ini untuk mengkaji tentang dinamika perkembangan pasar dan kasus keterlibat perempuan pekerja serabutan di Pasar Beringharjo, Yogyakarta. Metoda yang digunakan dalam penelitian ini metoda kualitatif dengan pendekatan etnografi. Hasil penelitian menjukkan bahwa Pasar Beringharjo selalu mengalami perubahan dari waktu ke waktu, baik secara bentuk fisik maupun aktor-aktor yang "menghidupinya". Perempuan pekerja serabutan menjadi salah satu aktor yang berperan penting dalam keberlangsungan kegiatan pasar yang begitu dinamis.
\end{abstract}

Kata kunci: Pasar tradisional; perempuan; perempuan pekerja; pasar Beringharjo

\section{INTRODUCTION}

Market as place which often been studied by anthropology may be divided in two categories, modern and traditional market (Endres, 2013; Nelwan et al. 2017; Saban and Prawira, 2018). Traditional markets are often known as shabby, dirty and smelly places (Nazib and Sosianika, 2017; Ardiansyah and Mahendarto, 2019). This assumption continues to stick with the market to this day. The impression is that traditional markets have never changed, or stagnated. In fact, the traditional market is a very dynamic space. When examined from the price point of view, a commodity is not priced at a fixed price, but is the result of negotiations through a bargaining process or a sliding price (Aliyah et al., 2016; Sudarno, 2016; Hermawan et al. 2018; Purnomo et al. 2018; Sabhan and Prawira, 2020). From time to time, traders like other actors, namely: traders of ngider (traders who do not have a stall/lapak), cleaning workers, porters always respond to various socio-economic events that occur internally and externally to the market where they trade (Supangkat, 2012).

Every day people who are active in the marketplace as an activate social relationships and use them as a place to make a profit. Thus, the market is not as simple as it seems. According to an anthropology researcher, Sumintarsih et al (2011: 4) trade in both rural and urban markets has a very complex trading mechanism in economic activities. Other opinion comes from Belshaw (1981; Direktorat Internalisasi Nilai dan Diplomasi Budaya, 2013), the emergence of the market is not only to provide an opportunity for selling and buying surplus products, but as a place to share work. Traditional markets as a place of trade need to be paid attention because there are jobs in the informal sector or small-scale trade which are full of risks (Effendi 2006: 53). These jobs are considered risky because they are easy to enter, but also easy to terminate. In practice, especially in developing countries, many actors are involved in trading in traditional markets. The market has become a concern and orientation for many 
members of society who are not having a fixed income, who cannot be absorbed in the formal sector and who do not have large capital to do business.

The actors in the market consist of both men and women. This article pays attention to working women in the market. Previous studies on traditional markets show an important link between traditional markets and women, because: (a) this market is a place for women who are 'thrown out' (terlempar) from other economic sectors (Abdullah, 1990; Boserup, 2011, Dewey, 1962; Stoler, 1975; Supangkat, 2012) (b) skilled women practice economic principles in seller-buyer social relations that are unique to traditional markets (Alexander, 1988, 2001, Seligmann, 2001,2004, 2018; Supangkat, 2012); (c) traditional markets are an important space for actualization 'self and women's autonomy (Gordon, 2009, 2011; Kutanegara, 2006; Supangkat, 2012); and (d) to support house hold economy (Sumarah, 2018). However, these studies treat traditional markets as merely a market place that is more or less steady. Even though the current economic development, especially in urban areas, has many affect the condition of traditional markets, which in turn also affects the sustainability of women's businesses in them.

Traditional markets are still generally found in many places in Indonesia (Sabhan and Perwira, 2018). In Java, the market or peken is a gathering place to exchange needs that exist throughout the region. In this market, thousands of people usually gather, especially women who bring their produce to exchange in the market (Raffles, 2014). Through this quote, it can be seen that the existence of women in the market has been around for a long time, at least when referring to the writings of Raffles (2014) which are listed in the book The History of Java since the 1800s researchers have described women as important actors in the sustainability of activities in the traditional market.

In another study, Abdullah (1990) explained that there had been changes in the employment sector, especially in rural areas. Gradually employment opportunities in the agricultural sector decreased, this resulted in increased involvement of activities outside of agriculture, especially in the service and trade sectors. Furthermore, the percentage of women's involvement in off-farm work is relatively high, for example, specifically in the case of small-scale trafficking, women have a more important role than men in Java. More recent research also states that traditional markets are synonymous with women, this makes women traders as key actors who have power and dominance in traditional markets, of course, become central in building relationship patterns with various other subjects that play a role in the market. For example: with husbands, with other traders, with buyers, with owners of capital, with suppliers of goods, with porters and laborers in arms (Fujiati, 2017).
Based on previous studies, it has tended that some women of all kind of works are less concerned by scholars.

However, traders are not the only actors who are important in a traditional market. The system that is built in a traditional market is not one-way, but between actors are interrelated and influence each other. In Beringharjo Market, casual women workers such as carrying laborers (buruh gendong), ocek workers, and gresek have also an important role in the traditional market. The purpose of this study was to examine the dynamics of market developments and special cases of involvement of women as worker of all kind of work (pekerja serabutan) in the Beringharjo Market, Yogyakarta.

\section{METHOD}

This research focuses on the practice of women working in 'all kind of work' in Beringharjo Market of Yogyakarta, which ethnographically will be presented in the discourse in this article. Ethnography as a research method which is used in anthropology research was used in this study because ethnography is the work of describing a culture. The goal is to grasp the native point of view, his relation to life, to realize his vision of his world (Spradley, 1980, 2007). Beringharjo Market is presented as a locus for the practice of women working as miscellaneous jobs. In practice, these women are not the sole actors and the Beringharjo Market is also not a monolithic locus, there are interactions with loci outside the Beringharjo Market.

In this anthropology study, the reading of the concept of culture is understood as flexible, negotiable, fought for, relative, and subject to change (King and Wilder, 2012: 318). The culture that is formed is then seen as a differential culture that grows from the continuous interaction between humans, groups and the environment that is constantly changing (Abdullah, 2015: 5). Through the description of the cultural concept in the previous paragraph, data collection in this study used observation techniques, in-depth interviews, and casual interviews and participation observation. In the observation technique, researchers made observations by involving with activities at the Beringharjo Market. Various considerations that are observed when making observations include the interaction or communication relationship of women working odd jobs with traders, with market visitors, and with other actors. The wowen that are observed were purposively selected based on competeness and consideration of diversity of commodities traded by women traders. For instance, women traders of vegetables, fruits, and flowers were purposively selected in this study.

Data collection also used in-depth interviews. The interview technique was chosen because it was used to collect historical data on the journey of women working 
in all kind of work, from the start of work to the end of the day. In-depth interviews are aimed at informants who feel they know in depth the required data. In this study, in-depth interviews were aimed at several actors, namely the embok-gendong, the mother of the ocek worker, the gresek woman herself, and the manager of the Beringharjo Market. In addition to in-depth interviews, the interview models used were unplanned interviews and casual interviews. These two interview models are aimed at the general public and are conducted randomly. This interview aims to complement and check the research data obtained during in-depth interviews. The interview model is often used by researchers when they are at a food stall, when they meet a random market visitor. This interview is also often used by researchers when making observations when looking at market conditions, or when making observations around the Beringharjo Market.

Analysis of research data used qualitative analysis which consists of four flow of activities, namely data collection, data reduction, data presentation, and drawing conclusions or verification. This process was carried out repeatedly to get a certain pattern in the society being studied. In conducting data analysis, the flow is not always sequential because these steps were intertwined before, during, and after data collection in parallel form, to build general insights called analysis. Meanwhile, in the data verification process, the researcher used triangulation, which is to compare the observed data with the data obtained during the interview. Researchers also compared interview data from one informant to another.

\section{Study site}

This research was conducted in Beringharjo Market, Yogyakarta City. Beringharjo Market itself is located on Jl. Margo Mulyo No.16, Ngupasan, Gondomanan subdistrict, Yogyakarta City, Yogyakarta Special Region (Figure 1). Beringharjo Market was chosen as the study site because of its character as a traditional market that has existed since the days of the Islamic Mataram Kingdom and has survived until now. Beringharjo Market was also chosen as a representation of the Javanese market which continues to experience its journey and is covered with changes over time.

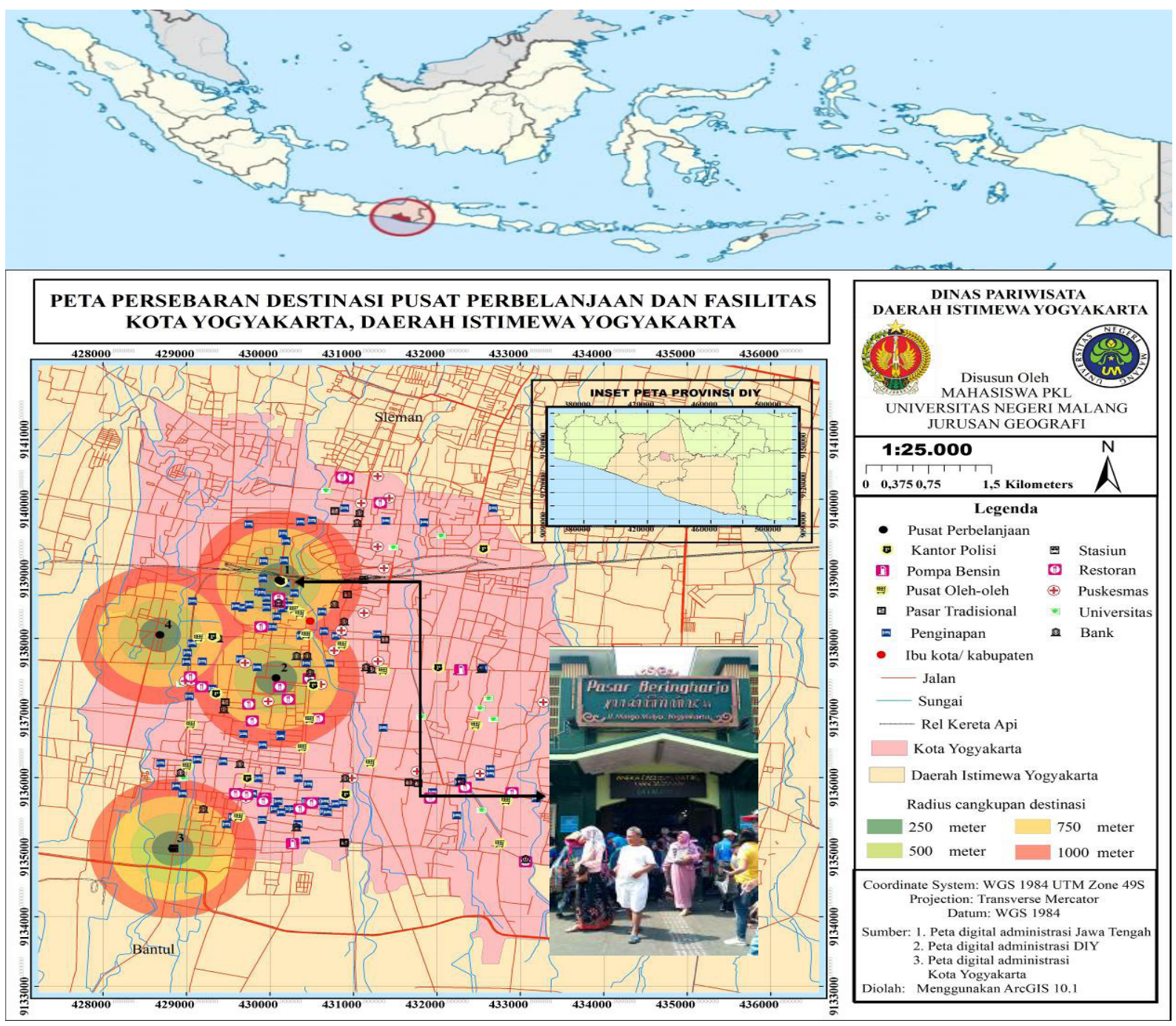

Source: Documentation of Bappeda of Yogyakarta \& Bappeda.jogjaprov.go.id (2019)

Figure 1. Map of study site location, Beringharjo, Yogyakarta 


\section{RESULT AND DISCUSSION}

\section{Beringharjo Market}

The name Beringharjo is taken from the words bering and harjo, according to one of the informants (Head of East Beringharjo market, about 49 years old) the word 'bering' means a banyan (beringin tree-Ficus benyamina $\mathrm{L}$ ) this is based on the location where many large banyan trees used to be, while the word 'harjo' means prosperous. In the early days, it is said by some traders, traders used simple stalls made of wood or just bamboo mats for trading. The Beringharjo Market building itself was built during the reign of Sultan Hamengkubuwono VIII, the palace teamed up WIBh Nederlansch Indisch Beton Maatschappij (Dutch Indies Concrete Company) in 1923-1925 to build market booths (Direktorat Internalisasi Nilai dan Diplomasi Budaya, 2013). The results of this development can still be seen today as the entrance to the Beringharjo market on the West side (Figure 2).

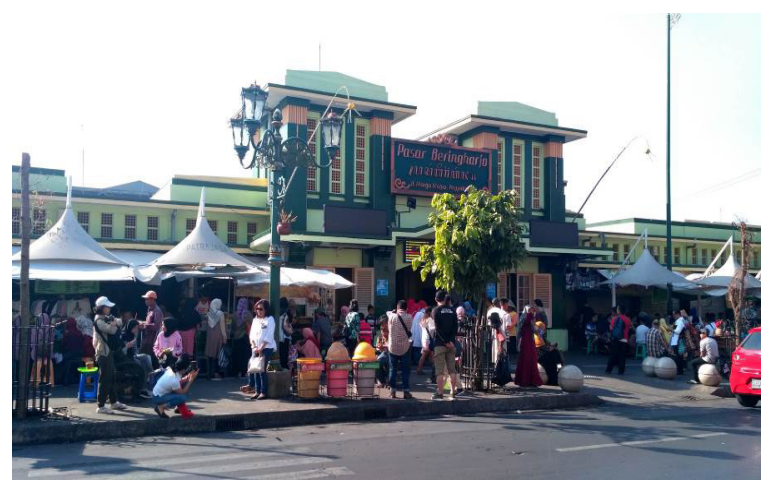

Source: Researcher documentation (2019)

Figure 2. Market building of West side Beringharjo Market

\section{Beringharjo Market from morning to night}

Unlike other markets in Java or village markets as described by Koentjaraningrat (1994), the market has Javanese market days (such as Kliwon, Legi, Pahing, Pon, and Wage), Beringharjo Market is open or operates every day (7 days per a week) without a day off. This is because Beringharjo Market is one of the big traditional markets in Yogyakarta City, which has a very fast economic turnover and is important for the survival of its stakeholder. The Beringharjo Market is formally operating from $07.00 \mathrm{WIB}$ to $20.00 \mathrm{WIB}$.

However, the operating hours are not synchronous in the three zones in Beringharjo Market. For example, the Eastern part of Beringharjo market began operating at 05.00 , the Central Beringharjo Market at 07.30 am of Western Indonesian time (WIB), and the West Beringharjo Market at $08.00 \mathrm{am}$ (WIB). Such formal times are not rigid, in some situations traders can open their kiosks or shops earlier or even after-market operating hours. As with markets in general, traders in Beringharjo Market also trade every day with no urgent need. There are several reasons why traders do not sell, among others; when having a need (such as having a desire, death of a family, etc.), when a neighbor or relative has an intention (a wedding, circumcision, or death usually applies to the closest neighbors or those who are still related by blood), and some have a day of abstinence that requires not selling (Javanese people usually have a taboo day in their life, this taboo day is calculated through the relevant weton. Usually in a month there is one day of taboo). The rest of the traders will always trade to make ends meet

Every day, activities at Beringharjo Market, especially in the East, start in the morning at 02.30 p.m (WIB) (Figure 3 ). At that hour, the door to the market was not fully open. Only the Eastern pavilion door was half opened and some side doors opened. Not all of the lights of the kiosks and shops inside are on, the part that is fully lit is the meat and fish seller block, while on the 2nd and 3rd floor the lights are not on, nor are the doors open. The activity that took place at that time was the process of loading and unloading goods, especially vegetables sent by the suppliers. This activity is centered in front of the Beringharjo East Market pavilion. Vehicles from several areas in Yogyakarta as well as some from around the Yogyakarta area take turns to unload their cargo. Although in the market the buying and selling activities have not yet fully taken place, the conditions in front of the Beringharjo East Market pavilion are not the same. Along the road around the Beringharjo East Pendopo, traders began laying out a base, usually made of tarpaulin, as a place to sell. Apart from around the pavilion, the traders also sell merchandise around the shop house located opposite the pavilion.

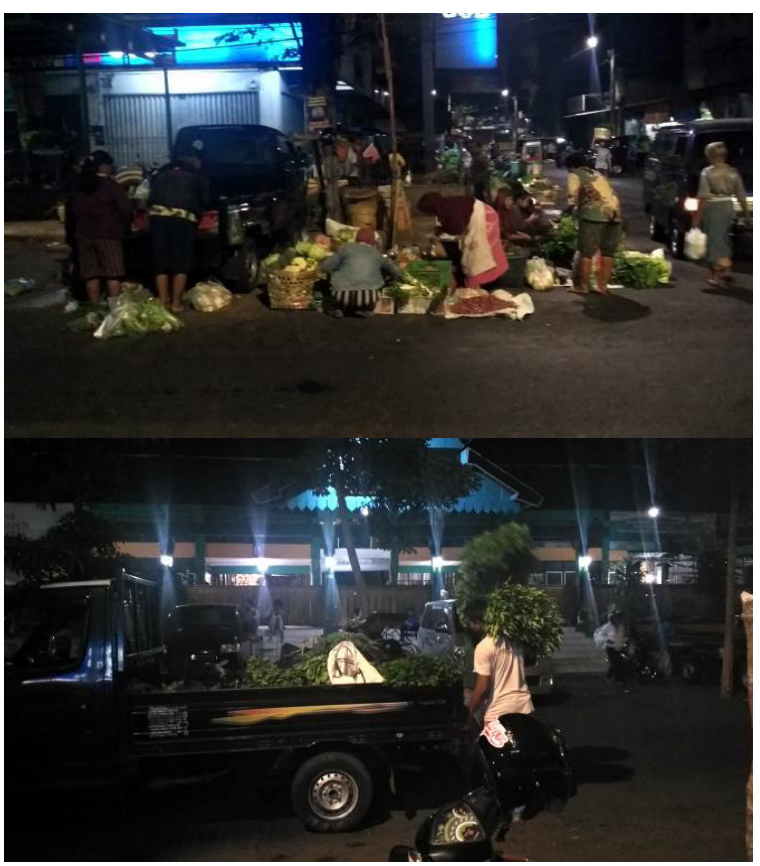

Source: Researcher documentation (2019)

Figure 3. Buying and selling activities in front of the East Beringharjo Market, residents also call it as the morning market. 
As mentioned earlier, almost all traders who sell along the street and overhang of the shop houses use the lesehan system, which is to arrange their merchandise on the ground on tarpaulin or just sacks. Most of the buyers who are regular customers or just shop are vegetable traders who resell the vegetables they bought from sellers at the Baringharjo morning market. These mobile vegetable sellers shop as early as possible so that they can immediately sell vegetables to their operational areas faster and in accordance with the cooking times of their consumers. These mobile vegetable traders can usually be identified by the vehicle they use, namely using a motorbike or pedal bicycle where the rear seats are equipped with a brojong (a type of basket made of bamboo) to transport their groceries. These sellers also sell fish, beef, chicken, various spices, and street snacks (including market food and typical market snacks in Java such as getuk, cetot, lopis, ketan, etc.).

The vendors selling in front of the pavilion and overhang of the shop houses were not only vegetable sellers, there were also hawker sellers (penjual jajanan), coconut sellers, angkringan sellers (nasi kucing sellersrice wrapped in small pieces usually contains rice, chili sauce, and a few side dishes like anchovies), various drinks such as coffee, tea, wedang ginger (hot ginger), and wedang jeruk (hot orange drink), as well as various kinds of fried foods. Such angkringan traders has been also been highlight by Santoso and Harsono (2014). These traders usually have their own subscriptions, several times seen the traders have prepared vegetables into large plastics and when the customers come, the buyers only need to pay and take the groceries. Usually in cases like this the buyer who becomes a subscription has ordered from the seller whatever is needed on the previous day, either directly or via cellular telephone.

The selling time of the traders this morning only lasted a short time, when it entered at 07.00 am (WIB) some traders began to be seen cleaning up their stalls. The characteristics of buyers who are mostly not retail buyers make the turnover of merchandise so fast. This can be seen from the many traders who sold at $07.00 \mathrm{am}$ (WIB) that many had run out. Some others remained until $07.30 \mathrm{am}$ (WIB), on weekdays the traders did not trade in the area after $07.30 \mathrm{am}$ (WIB) because from that time the shop houses would open (Figure 4). In addition to the shop house area, the sellers who sell around the pavilion must be clean when entering this time or "Pendopo must be sterile" because the place is not for trading but for gathering and meeting places.

Beginning 07.00 am (WIB), many of the traders inside the East Beringharjo Market have opened their shops (Figure 4), the vegetable sellers on the second floor have started to open and have activities. Starting at this time the process of activity, which was initially centered on the market, gradually moved into the market. The market began to look noisy with various conversations from the ongoing transactions. Like the vegetable traders outside the market, the vegetable traders inside have their own customers, both buyers and vegetable suppliers. The vegetable traders on the second floor sell daily from morning to evening (usually 15.00 - 16.00 pm WIB). As well as the kiosks that remain the reason these traders can sell all day long. Even so, the busiest time for vegetable sellers is in the morning, usually household buyers who meet the market in the morning, and food sellers who shop for vegetables to be resold as ready-to-consume food.

The vegetable sellers on the second floor get their supply of vegetables from several depositors who come from several areas such as Bantul, Muntilan and its surroundings. The vegetable depositor on the second floor did not always deposit vegetables in the morning. Several times, a supplier was also found depositing vegetables at noon to sell the next day. The sellers of vegetables, fruit, onions, and spices usually use wooden stalls or build stalls as places for them to trade. Most of the sellers of vegetables and spices (traders call them empon-empon- consisting of ginger/jahe-Zingiber officinale Roscoe, turmeric/kunyitCurcuma longa L, galanga/lengkuas-Alpinia galangal (L) Wild, temu kunci (Kaempferia rotunda L, etc.) are predominantly found using wooden stalls as a place to arrange various types of vegetables and empon-empon for

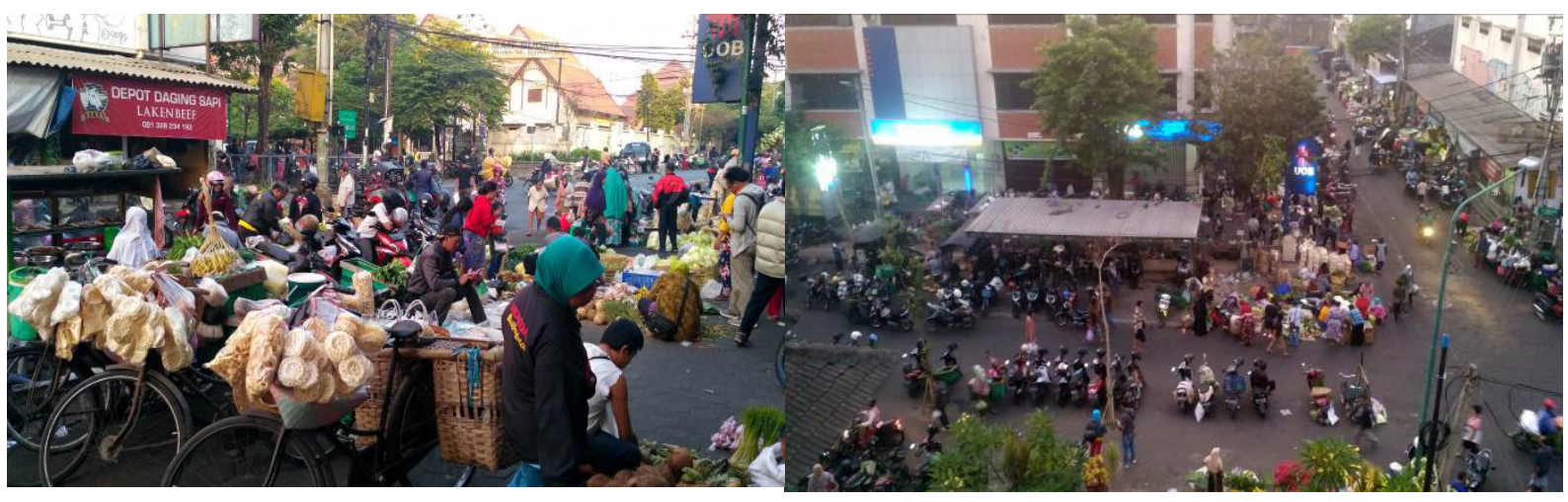

Source: Researcher documentation (2019)

Figure 4. Situation of early morning of East Bringharjo Market (left), mobile vegetable vendor using a bicycle (right) 
trading. Meanwhile, dry spice traders, and trading onions in the form of stalls made of wood (usually also coated with zinc made of iron so that they are not easily rotted).

After time of the busy time in the morning, the traders will continue other activities, namely sorting merchandise and preparing merchandise for sale tomorrow. Some traders will wait for the vegetable supplier to buy the vegetable supplies that have run out Meanwhile the others are also seen calling the supplier to order vegetables to be brought the next day. Apart from waiting for the supply of vegetables, some vegetable traders also prepare vegetables for their customers to order the previous day or ordered by telephone. His continued activity was sorting, which was sorting vegetables that could still be sold the next day and which were no longer fit for sale. In the onion trader, the sorting process is usually not done alone, there are people who help or offer their services to do the sorting. This sorting activity will usually end in the late afternoon (usually $14.00 \mathrm{pm}$ WIB) or when it is deemed sufficient. Traders basically do not have a strict time benchmark in carrying out activities as previously described. It was even seen that some traders had closed their stalls and returned home after Dzuhur time (at 12.00 WIB), "it's the worst to be annoyed "it will be finished when it's tired" (bare paling nak wis kesel) according to one of vegetable traders at East Beringharjo East.

\section{Female worker of all kind of work laborer at Beringharjo Market}

According to the market manager, the number of traders in Beringharjo Market recorded 5,553 traders consisting of 1,898 male traders and 3,655 female traders (Interview with the Head of the East Beringharjo Market, 2019). Based on this data, it can be understood that more than 60 per cent of Beringharjo Market stakeholders who work as traders are women. This number does not include other actors who support the "life" system (sistem kehidupan) of Beringharjo Market. In the previous discussion, it was explained that not all onion traders do sorting, usually someone offers a service for sorting onions and most of them are women. Through this in this section, the discussion focuses on the portrait of women who work odd jobs and are important for the continuity of the market "life" system.

\section{Female carrying laborer 'Embok Gendong'}

Embok gendong consists of two words, namely embok and carrying. Embok is a Javanese call for mother, while gendong means lifting or carrying. When it means embok carrying it means women who involve in carrying trader goods. The mention of embok itself is because most of the women who work as transport workers have an age that has passed their adolescence. Throughout the research, it was almost never found that women who work as transport laborers are still young or have children.

Embok gendong itself is a social phenomenon that is rarely found in most markets in Java, especially. In general, men who often work as transport workers are men, but in Beringharjo Market the phenomenon of female transport workers has been practiced for a long time. Not much can be gathered from the Embok gendong since when this phenomenon began to exist. The existence of women as transport laborers has existed since the colonial period, maybe even before. Embah Parinem (pseudo name, about 70 years), for example, told that since he was a child the phenomenon of the Embok gendong has existed because his mother used to be a carrier. Initially, only the aristocracy or high social class used their services, this Embok gendong carrying was seconded to lift groceries from the market.

According to the head (lurah) of the Beringharjo Market, the number of Embok gendong in Beringharjo Market is recorded approximately 200 people. This amount is the amount recorded by the market manager. Currently Embok gendong in Berigharjo Market come from several areas in Yogyakarta, such as Kulonprogo Regency, Sleman Regency, as well as several areas around the Beringharjo Market. The largest number of Embok gendong comes from Kulonprogo Regency. Every day the Embok gendong spends time in the market, some of them even sleep around the market. Although not all, there are those who start their activities since the morning before dawn, when the process of unloading vegetables in the morning. Starting at $02.30 \mathrm{pm}$ WIB, several Embok gendong of vegetables were seen waiting on the steps of the pavilion waiting for the vegetable supplier to deposit the vegetables every morning (Figure 5).

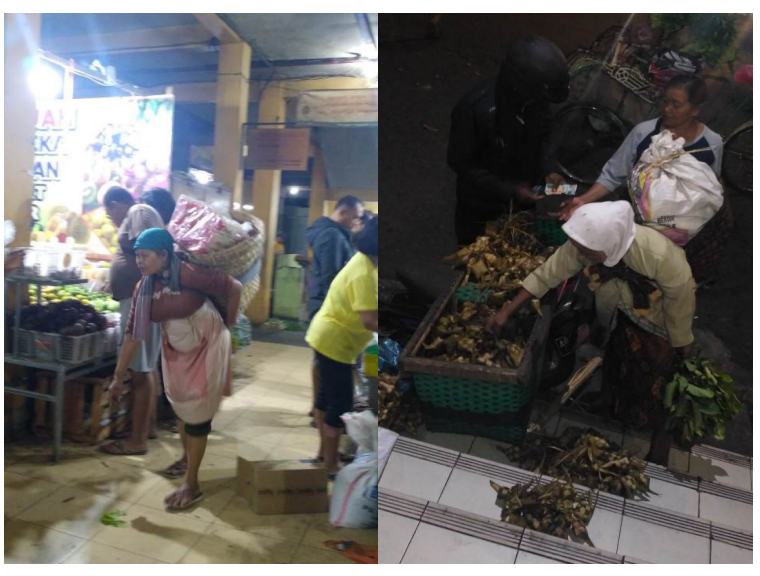

Source: Researcher documentation (2019)

Figure 5. Activities of Embok gendong are undertake in the early morning

These Embok gendong usually have memorized the traders in Beringharjo Market. The depositor who assists the Embok gendong usually only has to say the name of the merchant to the Embok gendong. Some suppliers also 
have their own subscriptions; in this case the other carriers know who are the suppliers of the Embok gendong 's carriers. Every time a car comes carrying vegetables, the Embok gendong will immediately come over to pick up the vegetables that have been deposited. Several times, the Embok gendong usually did not ask first, but immediately got ready to lift the vegetables. The supplier also seemed to understand and immediately informed the vegetables being delivered to the traders. After the vegetables that have been deposited and have been delivered, the Embok gendong will get a fee from the vegetable supplier.

The amount of fees paid by service users is never standard because the Embok gendong itself never determines how much it must pay. According to Mbah Parinem that "If I sincerely give it, given a lot I thank you, given a little I am grateful. Fortune has already arranged" (nak kulo niku mpun saikhlase ingkang maringi mawon, dipun paring kathah nggih matur nuwun dipun paring kedik nggih bersyukur. Rejeki mpun wonten ingkang ngatur). In addition to waiting for supplier subscriptions, in other cases the Embok gendong has often been ordered by the merchant to deliver the merchandise she has ordered from the supplier that day or the next day. In connection with this phenomenon, Embok gendong are usually not paid for by the vegetable supplier but by the traders who order services to him.

As a person who work in the market, there is a strong solidarity between the gendongs. The solidarity that is built among the Embok gendong is so intimate, each Embok gendong does not have the feeling of being competitive with the other Embok gendong carriers. The Embok gendong will not take customers from another Embok gendong, unless in certain situations, such as pre-ordered or the Embok gendong cannot work, then its closest friend will replace the role of the hanger Embok gendong. In the Beringharjo Market itself, the Embok gendong has an association where they are organized and recorded. This association member usually meets once a month or at certain times. Through these associations, usually aid from the government or the private sector is easier to distribute because the Embok gendong are well recorded.

The gendong's association is also intended to strengthen the relationship between the Embok gendong to get to know each other. Every Embok gendong who enters the association or association will get a membership card (Figure 6). Apart from being an identification card, this card also serves as a guarantee that the Embok gendong carrying its rights are protected. It is not uncommon for the government through the market manager to provide trainings or health services for the Embok gendong carrying in Beringharjo Market, and what is prioritized is the Embok gendong carrying the association card or which has been registered by the market manager.।

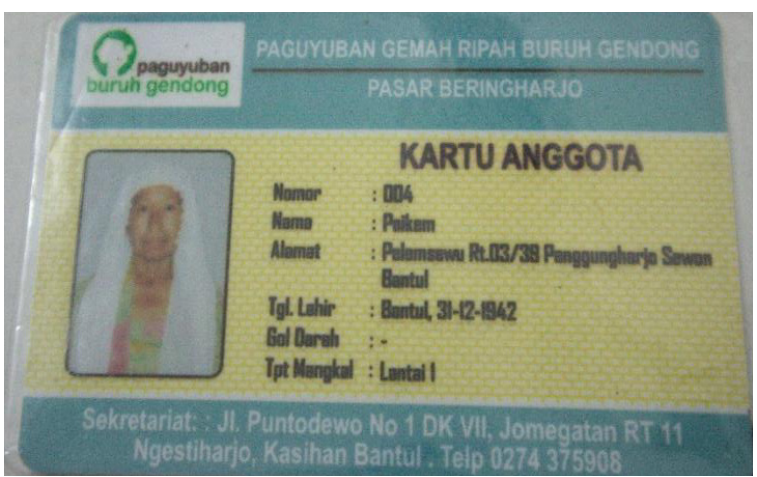

Source: Researcher document (2019)

Figure 6. The card member of Embok gendong Association of Beringharjo Market

Many Embok gendong who work at Beringharjo market are of advanced age. Some of the reasons expressed by one of the Embok gendong carrying, among others, are feeling healthy, not infrequently the Embok gendong decides to keep working because it feels physically strong enough to work; the second is that they do not want to bother their relatives like children. This reason is most often encountered by researchers when talking about their reasons for continuing to work even though they have entered old age; and the third is a psychological factor, such as being bored when you have to be at home without doing anything in the end what happens is a sense of uselessness and a burden to the family. One Embok gendong said that:

"alesanipun tetep gendong kados niki nggih mboten purun ngerepotke anak, pokoke nak ragane tasih kiat nggih kudu tetep kerjo. Mangke nak mboten kerjo ting dalem malah stress wong mboten ting pundipundi mboten angsal penghasilan. Nak ngeteniki kan gadhah rasa bingah ketemu rencang-rencang akhire mboten stress." (Wawancara dengan salah satu embok gendong di Pasar Beringharjo, 2019)

It can be translated as:

"The reason is that you are still carrying (being a carrying labor) like this because you don't want to be a bother to your children, basically while your body is still strong you must keep working. Later, if you don't work at home, you will be stressed because you are not going anywhere and you have no income. If it's like this, you have a sense of happiness to meet friends in the end you won't be stressed. " (Interview with one of the Embok gendong carrying at Beringharjo Market, 2019).

Based on the informant statement above, it can be understood why some women involved in women worker of all kind of work, actually she has special perception on her work. Based on both the economic macro research and stakeholders of the market economy system, the fate of women workers of all kinds of work in urban markets is often neglected. 
Nowadays, one of the obstacles for the Embok gendong, especially those who have entered their old age, is that the multi-store market building makes the cradles need extra energy to lift goods. Several times the researchers found that the Embok gendong, especially the elderly, stopped before or after climbing stairs. The items that the Embok gendong have to carry a weight that varies from $5 \mathrm{~kg}$ to $30 \mathrm{~kg}$. Every day the Embok gendong not only go one lift but several times up and down the stairs. Some of the elderly Embok gendong decide to only operate on the 1st floor, which does not need to go up and down stairs but with a different income consequence. Some of the others continued to operate on the second floor to lift vegetables, fruit, onions, and various other merchandise.

The existence of the Embok gendong in Beringharjo Market can be said to be important for the continuity of the market's "life" system (Figure 7). The Embok gendong makes it easy for traders by reducing one workload, namely the lifting of merchandise. In addition, it is not uncommon for traders to ask for help from the Embok gendong to keep the shop, or to buy merchandise that runs out to the nearest shop. Apart from that, with a good relationship between the Embok gendong and the traders, it is not uncommon for the Embok gendog to carry the direction of the buyers who are looking for certain items to the regular traders who use their services. In other words, the Embok gendong holding becomes a marketing agent for the traders. Apart from traders, the Embok gendong is also useful for market visitors in terms of lifting groceries. This provides a sense of calm for market visitors when shopping in large quantities.

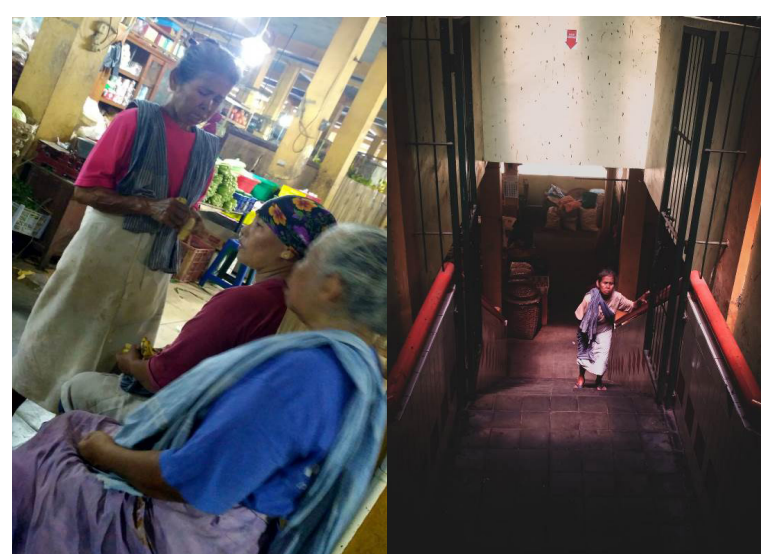

Source:Researcher documentation (2019)

Figure 7. Few Embok gendong are recorded in market

\section{Female workers as ocek labor and picking labor}

One of the market actors whose existence is rarely noticed by the general public is the ocek and picking labor. In Javanese ocek itself means peeling. In large traditional markets such as Beringharjo Market, the existence of ocek and picking workers is an important part of traders. Not a few consumers, usually from certain restaurants, order certain types of commodities from sellers, such as clean peeled onions and garlic or chilies, some consumers even ask specifically for sliced shallots. To fulfill this demand, traders (such as shallot traders and seasoning traders) must provide goods/commodities ordered by consumers. The existence of such a request also makes the services of motorcycle taxi and picking workers available.

Every day ocek workers arrive at the market at 07.30 am WIB or after spice traders open their shops and stalls. There are not many ocek workers who are in Beringharjo Market, one of the motorcycle taxi drivers said that at most in Beringharjo there are only 20 people who work as ocek and picking workers. Even though the number is small, it does not mean that these women motorcycle taxi and pick-up workers get regular jobs every day. Demand for commodities such as peeled and sliced onions is fluctuating so that the demand is not fixed every day. This is usually influenced by economic conditions or certain times. Demand for these commodities usually comes from restaurants, caterers, and hotels, where the needs are also influenced by visitors. Usually during the holidays and nearing the holiday, the demand for peeled onions and chili peppers will increase. This condition ultimately affected the income of ocek and pick workers in Beringharjo Market. All of the stakeholders who work as ocek and pick workers are women, it is very rare to find male coke workers. At the time of doing the research, there were never any male coke workers.

Every morning when they arrive at the market, these coke laborers will come to stalls and shops selling spices to ask if you have peeled anything on this day or not. Each coke worker usually has his own subscription, so that the coke worker does not come to just any trader. After the merchant agrees, the coke worker will take the onion according to the merchant's request. In a day, experienced ocek workers are able to peel $10-15 \mathrm{~kg}$ of onions. If the demand is large, the amount can be even higher, but when the demand is low, the amount can only be $5-10 \mathrm{~kg}$ a day. The fee to be paid for this service is Rp. 2000, - Kg for peeling shallots and garlic, and Rp. 1000, - / kg for chili picking services.

One of the ocek workers told us how she started being an ocek worker until now. Her name is Mbak Emi (pseudo name, about 48 years old) tells that when she started working as an ocek worker, she was not a native of Yogyakarta but a resident born in Wonosobo. In the past, she went to Yogyakarta to try her luck by helping her brother sell vegetables at Giwangan Market. After running for several years, Mbak Emi wanted to be more independent and decided to move to Beringharjo Market. Arriving at the Beringharjo Market, Mbak Emi met one of the ocek workers' mothers, then she asked her. Emi to be a good guy too. Initially, Mba Emi planned to become a Embok gendong laborer but when she saw that there 
were many workers in Beringharjo, finally Mbak Emi agreed with an offer from one of the ocek worker mothers. Mbak Emi being a ocek worker is a comfortable and fun job because in addition to working to earn income, while peeling it is not uncommon to be seen chatting with fellow ocek workers. That kind of feeling made Mba Emi is comfortable working as an ocek worker, even though the income she receives is uncertain. Most of the ocek and petil workers in Beringharjo Market are elderly women (Figure 8), usually these women used to be Embok gendong but because of their limited workforce they decided to become ocek workers so they could still earn income.

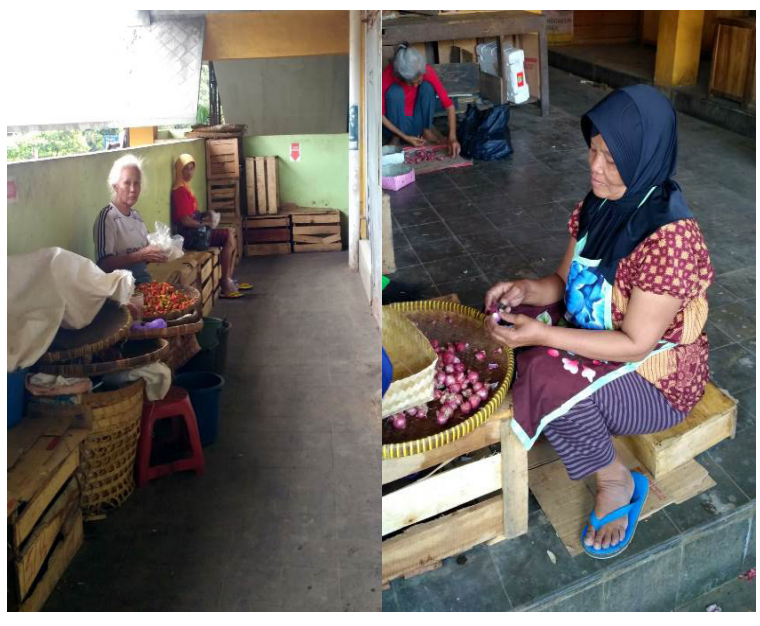

Source: Researcher documentation

Figure 8. Mbak Emi is peeling onion (left) and one of picking labors in Bringharjo market (right)

Female good Scatter collector (gresek): Recycler good scatter female

Gresek comes from the Javanese language which means collecting for remains. This practice was originally used to refer to the activities of collecting for leftover crops in the fields or in the fields carried out by the village community. Over time this practice was also carried out in the market by some people. In Beringharjo Market, some women work as freshmen. This profession is not widely practiced by people in the market, as long as the research the researchers only met three women who were new professions. Gresek itself is used to describe activities, while people who do gresek activities are called gresekan. According to one gresek mother, gresek is different from scavengers. For example, Bu Jumilah (pseudo name, about 51 years) explained that gresek only took the remnants of commodities traded by traders (such as shallots that fell to the ground, or commodities that were scattered during the unloading process from suppliers), in contrast to scavengers who took anything provided of value (such as plastic bottles, metal, etc.).

Every day the gresek worker is around the loading and unloading location on the second floor and also around the blocks selling onions and herbs (empon-empon) which are also not far from the loading and unloading location.
Gresek worker can be identified by the equipment they use for grinding. The equipment is a bag made of plastic and attached to a bamboo as a handle, this bag is used to accommodate commodities that are found when grinding; the other tool is a long bamboo, almost like a fishing rod, which is used to pick up commodities that fall between shops or merchant stalls (Figure 9). Gresek's worker always goes around the onion traders who do sorting by ditapeni (sorting using tampah like sorting rice) to pick up the remaining onions that have fallen during the sorting process. Even so, when the process of unloading the cargo, this new lady will wait around the truck carrying the commodities to be deposited.

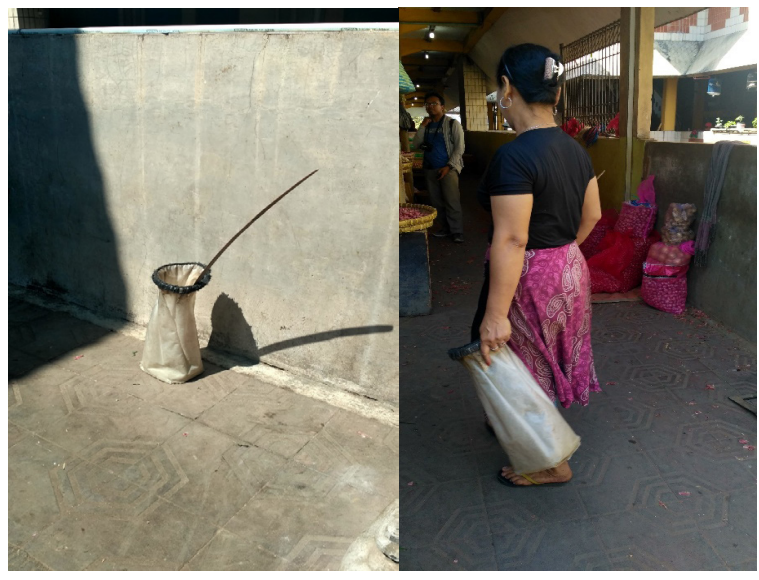

Source: Researcher documentation (2019)

Figure 9. Some tools of gresek (left) and the female gresek worker

Commodities obtained from this gresekan are then collected for retail resale or processed into other trading goods or just to meet daily food needs. For example, when $\mathrm{Bu}$ Jumilah get a bit of red onion, she will sell the shallots back to neighbors or to other traders who want to accommodate them. But when she got a little result she would collect it first. It is different for vegetables that are taken such as carrots that fall or potatoes that fall from trucks, these ingredients will be cooked to meet food needs. Unlike the scavengers, the orientation of the gresek worker is not always on the economy but rather on how to use the leftover materials as efficiently as possible. This makes the presence of gresek worker in Beringharjo Market important, because with the presence of gresek worker, leftover vegetables or other commodities can be minimized and used efficiently.

\section{CONCLUSIONS}

To sum up, the traditional market, especially Beringharjo Market, is the place for traders and buyers to carry out their activities. Furthermore, the traditional market is not only a place but also a system, in which there are actors who are interconnected and influential with one another, and make the Beringharjo Market. 
Market "alive" until it is continuously cared for by its stakeholders. Some of the actors who are part of this system are traders and women as worker of all kind of work (kerja serabutan). Each of these actors have different duties and functions but are related to one another as well. Such as Embok gendong who is useful for helping traders and buyers in lifting goods and as sales marketing that delivers buyers to their regular sellers. Other actors such as ocek workers whose function is to assist traders in fulfilling consumer demand for the necessary commodities, if these ocek workers are not available, there is a possibility that the supply of commodities, such as peeled onions and chili peppers will also be disrupted which also results in disruption of catering and food businesses.

Based on this study, it can be concluded that Beringharjo Market always changes from time to time, both physically and the actors who "live it". Women who work as worker of all kind work become one of the actors who play an important role in the sustainability of market activities that are so dynamic. Because the women workers who have been involving all kind of works have been predominating in the urban traditional market of Indonesia, more attention of stake holders for them must be given. This is in line with the sustainable development programs, including end of poverty in all its form every where, and achieve gender equality and empowerment and women in obtaining income in involving as women worker of all kind of work in the traditional market.

\section{ACKNOWLEDGMENT}

The research on which both this research and this article is based would not have been possible without the financial support of the SIMLITABMAS, Ministry of Research and Technology for funding the research project of Dr. Budiawati Supangkat MA, Decree Number 10/E1/KP.PTNBH/2019 and Agreement/Contract Number 5097c/UN6.G/LT/2019. We would also like to thank Dinas Perdagangan, Industri dan Pasar, Yogyakarta, Indonesia who permitted conducting this research. We also like to thank all informants, namely traders and Mbok Gendong of Bringharjo, Yogyakarta for cooperation with this research.

\section{REFERENCES}

Abdullah, I. (1990). Wanita ke Pasar Studi tentang Perubahan Sosial Ekonomi Perdesaan. Jurnal Populasi, 1, (1), 23-33.

Abdullah, I. (2015). Konstruksi dan Reproduksi Kebudayaan cet. V. Yogyakarta: Pustaka Pelajar.

Alexander, J. (1987). Traders, Trader and Trading in Rural Java. Singapore: Oxford University Press
Aliyah, I., Setioko, B., \& Pradoto, W. (2016). The Roles of Traditional Markets as the main component space (Case study: The City of Surakarta, Indonesia). IAFOR Journal of Sustainability, Energy, Energy \& Environment. 3, (1), 103-120. https://doi. org/10.22492/ijsce.3.1.06.

Ardiansyah, N \& Mahendarto, T. 2019. Rivitalizing and Reimagining the Indonesian Traditional Market (Case Study: Salaman Traditional Market Indonesia). IOP.Conf. Series: Earth and Environmental Science. 436, (2020), 012010. doi: 10.1088/1755-1315/436/012010.

Belshaw, C. (1981). Traditional Exchange and Modern Markets. Englewood Cliffs. N.J: Prentice-Hall

Boserup, E. (2011). Women in Economic Development. London New York: Earth Scan Publishing.

Dewey, A. (1962). Marketing in Java. Glencoe, III. : Free Press

Direktorat Internalisasi Nilai dan Diplomasi Budaya, (2013). Menguak Pasar Tradisional Indonesia, PT Mardi Mulyo

Effendi, N. (2006). Keberadaan dan Fungsi Pasar Tradisional: Jurnal Antropologi VII/1. Padang: FISIP Universitas Andalas

Endres, K.W. (2013). Traders, markets, and the state in Vietnam: Anthropological perspectives. ASEAS - Austrian Journal of South-East Asian Studies, 6, (2), 356-365.

Endres, K.W; Lethkowich, A.M. (ed). (2018). Traders in Motion: Identities and Contestation in the Vietnamese Marketplace, Cornel University Press.

Fujiati, D. (2017). Perempuan Pedagang dan Pasar Tradisional. Jurnal Muwazah, 9, (2), 106-124.

Gordon, K.E, (2009). Marketplace Vendors, Decision Making and The Household in Bolivia, in Economic Development, Integration and Morality in Asian and the Americas Research in Economic Anthropology, Emerald Group Publishing Limited. 29, 123146.

Gordon, K.E. (2011). What is Important to Me is My Business, Nothing More: Neoliberalism, Ideology and the Work of Selling in Highland Bolivia, the American Anthropological Association. XXXII, Number 1 \& 2011.

Hermawan, F., Kristiani, F., Ismiyati. (2018). Model of Indonesian Traditional Market Revitalisation: Case Study of five Metropolitan Cities in Java Island. Advanced Science Letter. 24, 3146-3151. 
King, V.T. \& Wilder, William D. (2012). Antropologi Modern Asia Tenggara Sebuah Pengantar. Terjemahan Hatib Abdul Kadir. Yogyakarta: Kreasi Wacana.

Kutanegara, P.M. (2006). Perdagangan: Kosmologi dan Konstruksi "DuniaWanita". dalam Sangkan Paran Gender. Irwan Abdullah (ed). 2001. Pusat Penelitian Kependudukan. Yogyakarta: Universitas Gajah Mada Press.

Nazib, M.F \& Sosianika, A. (2017). Retail Service Quality in Indonesia: traditional versus modern market. Academy of Marketing Studies Journal, 21 (2), $1-12$.

Nelawan, J.W., Lapian, S.I.H.V. \& Rumokoy, F. (2017). The Existence of Traditional Market Toward Modern Market in Tomohon City. Journal EMBA. 5, (3), 3348-3355.

Purnomo, M., Otten F, \& Faust H. 2018. Indonesian Traditional Market Flexibility Admidst State Promoted Market Competition. Social Sciences. 238; doi:10-3390/soci7110238.

Raffles, T.S. (2014). The History of Java, cet. 3. Terjemahan Eko Prasetyaningrum. Yogyakarta: Penerbit Narasi.

Rodriguez, J \& Fortier T. (2007). Cultural Memory Resistance, Faith and Identity. Austin Texas: University of Texas Press.

Sabhan, H. \& Perwira, I. 2018. Empowerment of Traders and Traditional Market Potential Development in Indonesia. International Journal of Innovative Science and Research. 3, (1):428-436.

Santoso, S. \& Harsono, J. (2014). Pola Solidaritas Kelompok Pedagang Angkringan Di Kota Ponorogo. Sosiohumaniora, 16, (1): 62-69. DOI: https://doi.org/10.24198/sosiohumaniora. v16il

Seligmann, L. J.(ed). (2001). Women Traders in CrossCultural Perspective: Mediating Identities, Marketing Wares. Stanford, California: Stanford University Press.
Seligmann, L.J. (2004). Peruvian Street Lives, Culture, Power and Economy among Market Women of Cuzco, university of Illinois

Seligman, L.J. (2018). Space, Place and Contentious Politics of Market Redevelopment, in Endres, K.W; Lethkowich, A.M. (ed) Traders in Motion: Identities and Contestation in the Vietnamese Marketplace, Cornel University Press.

Spradley, J. (1980). Participant Observation. Holt, Rinehart and Winston publisher University of Minesotta.

Spradley, J.P. (2007). Metode Etnografi. Terjemahan Misbah Zaulfa Elizabeth. Yogyakarta: Tiara Wacana.

Stoler, A. (1975). Land, Labour and female in Javanese Villlage. New York: Department of Anthropology, Columbia University

Sudarno. (2016). The Implication of Traditional Market Development for Governance of Conflicts: An experience from Klewer Market of Surakarta, Indonesia. Journal of Government \& Politics. 7, (4), 619-639. http//dx.doi.org/10.18196/ jgp2016.0045.619-639.

Sumarah, A.P. (2018). The Existence of Women Creating Cakes in Traditional Markets in Supporting the Family Economy and the Survival Strategy. Advances in Social Science, Education and Humanities Research. 23:393-395. http:// creativecommons.org/licences/by-nc/4.0.

Sumintarsih (Ed). (2011). Eksistensi Pasar Tradisional. Relasi Dan Jaringan Pasar Tradisional di Kota Semarang Jawa Tengah. Balai Pelestarian Sejarah dan Nilai Tradisional Yogyakarta

Supangkat, (B). 2012. Pasar Dan Perempuan Pedagang Di Pasar Ujung Berung Bandung. Disertasi pada Departemen Antropologi, Universitas Indonesia (tidak diterbitkan). 